\title{
Analysis of the Effect of E-Service Quality, Website Quality, Mobile Application Quality on Customer Satisfaction (Case Study at Shopee and Tokopedia)
}

\author{
Naim ${ }^{1}$, Dr. Wahyu Hari Haji, S.Kom., MM ${ }^{2}$ \\ ${ }^{1}$ Master of Management, Mercu Buana University, Jakarta, Indonesia \\ ${ }^{2}$ Lecturer of Postgraduate, Mercu Buana University, Jakarta, Indonesia
}

\begin{abstract}
E-commerce competition in Indonesia is highly competitive. Shopee and Tokopedia, as the two most extensive e-commerce services in Indonesia, have high promotion costs for user acquisition. In order for high promotion costs to be effective, high customer satisfaction is essential. This study aims to find the influence and relationship between e-Service Quality, Mobile Quality Apps website quality on Marketplace Shopee customer satisfaction, and Tokopedia. The object of this study is users who have used the Shopee or Tokopedia marketplace, both through the Website and Apps (apps), and live in Indonesia. A total of 400 respondents participated in this study, 200 respondents filled in the Tokopedia online questionnaire, and 200 respondents filled the Shopee questionnaire. Data analysis was performed using descriptive analysis, pivot tables, and statistical analysis using the Structural Equation Modeling (SEM) - Partial Least Square method and processed using Smart PLS 3.0. The results showed that e-Service Quality, Website Quality and Mobile apps quality had a positive and significant effect on Customer Satisfaction, both in the Shopee marketplace and the Tokopedia marketplace.
\end{abstract}

Keywords:- Customer Satisfaction, Marketplace, SEM PLS.

\section{INTRODUCTION}

In the industrial era 4.0 in Indonesia, the growth of internet users in Indonesia from year to year continues to increase, as disclosed (Adellia \& Prasetio, 2016) that data on e-commerce transactions in Indonesia is Rp. 25.1 trillion in 2014, which continues to increase every year, namely IDR 69.8 Trillion in 2016 to reach IDR 108.4 Trillion in 2017. This data proves that both big business players and individual business players are also affected by the increase in internet access in Indonesia . In addition to the growth of internet users, the increasing growth of mobile phone users and Indonesia's domestic growth of around 5\% are also factors that make Indonesia increasingly attractive to many e-commerce players, both domestic such as Bukalapak, Tokopedia and Blibli as well as players. international e-commerce like Lazada and Shopee.

The competition map for e-commerce in Indonesia is very tight, and with the very rapid changes in consumer preferences, maintaining a position in the competition among e-commerce players is a formidable challenge. Based on data released by IPrice (2019), a map of competition between local and international e-commerce in Indonesia is illustrated.

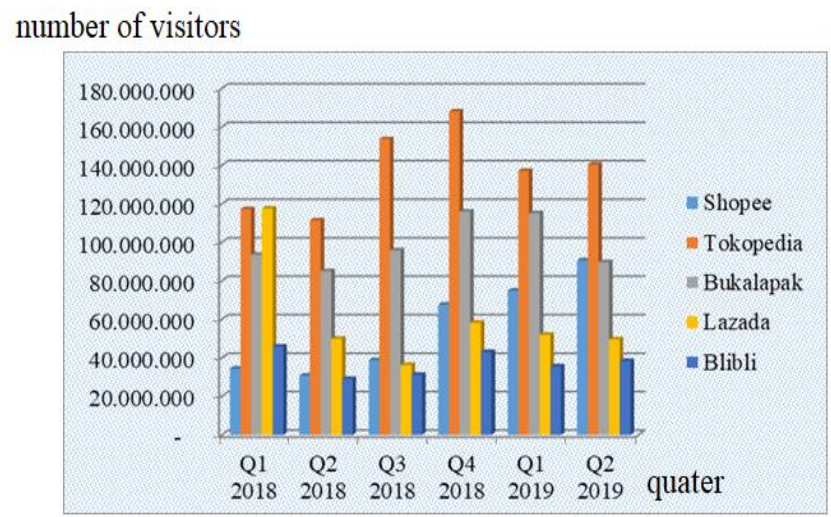

Fig 1: - Data processed by e-commerce maps in Indonesia Source: IPrice (2019)

In Figure 1 Lazada occupies the highest position with $117,573,100$ website visitors in the first quarter of 2018, followed by Tokopedia 117,297,000 visitors, Bukalapak $93,589,900$ visitors and Shopee in fifth place 34,510,800 visitors. In the second quarter of 2018 there was a drastic decrease in Lazada with only 49,990,700 visitors, Tokopedia experienced a slight decrease with $111,484,100$ visitors, Bukalapak 85,138,900 visitors, Blibli 29,044,100 and Shopee $30,843,400$ visitors. In the third quarter of 2018, all E-Commerce sites experienced a drastic decline, with Tokopedia remaining at the top with $153,639,700$ web visitors, Bukalapak 95,932,100, Shopee 38,882,000, Lazada 36,405,200 and Blibli 31,303,500 visitors.

From the figure, it can be seen that during the 4 semesters of the 2018 - 2019 period, the Lazada Site experienced a drastic decrease in visitors, while the Tokopedia site was constantly in the top position followed by Bukalapak. The Blibili site remains at the bottom of the ranking during this period. Shopee seems to have recorded a constant and significant increase in the second quarter of 2019 compared to the second quarter of 2018 with a $200 \%$ increase in website visitors year on year. 
Based on the data in Figure 1, there is a contrast difference between global e-commerce, namely Lazada which has experienced a drastic decline, and Shoppe which has experienced a significant and constant increase as well as intense competition between the two domestic $e$ commerce companies Bukalapak and Tokopedia in attracting visitors to their website shows that $e$-commerce is facing challenges in maintaining its position.

The map of $e$-commerce competition in Indonesia also occurs in mobile applications, as data released by IPrice (2019) is based on secondary data sourced from IPrice (2019) regarding the map of competition between ecommerce in positioning its mobile application as the most widely used application. It is known that the competitive map for ranking mobile applications on e-commerce in Indonesia shows that Shopee is constant as the first rank since the first quarter of 2018 to the second quarter of 2019 , while Tokopedia has a significant change in ranking with Lazada, Bukalapak is in fourth position, and Blibli is in fifth position.

Shopee and Tokopedia are the two largest ecommerce services in Indonesia (iPrice, 2019). Shopee was ranked first in mobile access from the first quarter of 2018 to the second quarter of 2019, while Tokopedia has several times exchanged positions with Lazada in second place. This shows that Shopee is more popular than Tokopedia, supported by high promotional costs.

High promotional costs indicate that Shopee and Tokopedia user acquisition costs are also high, and with lots of competition between e-commerce providers, high customer satisfaction as the key to customer loyalty is very important so that high costs are not wasted because problems that customers encounter when using $e$ commerce, especially from process constraints (customer service, slow disbursement of money, fraud / fraud, as well as variations / inaccurate stock of goods), as well as products (wrong delivery, damaged / defects and incorrect specification information) (Putri et al., 2017)

Based on the description of the problem and previous research related to customer satisfaction with various types of variables, our researchers conducted a pre-survey to find variables that were in accordance with this research, namely promotional variables, web quality, mobile apps quality, marketing mix services $7 \mathrm{P}$, e-service quality and brand equity and the results of the pre survey showed that $15 \%$ of 50 respondents answered that mobile applications were the most preferred as a variable of customer satisfaction, followed by Website quality and E-service quality, respectively $9 \%$. Therefore, interesting research and conducting further research on the quality of online services (e-service quality), mobile apps quality, and website quality from user experience access owned by Tokopedia and Shopee are expected to show how customers behave towards quality mobile apps and website quality and its effect on customer satisfaction at Shopee and Tokopedia.

\section{THEORETICAL REVIEW}

\section{A. e-Service Quality}

Wolfinbarger \& Gilly (2003) stated that $e$-quality service is something far from being limited to the appearance of a website, but also supports information search, product evaluation (review), decision-making processes, purchasing processes, customer service, delivery processes to product returns and money. (Rafiq et al., 2012).

E-service quality can be measured by a model developed by (VA Zeithaml et al., 2002) which divides $e$ service quality into 5 quality dimensions in electronicbased services. (Parasuraman et al., 2005) developed an instrument to define and measure $e$-service quality, namely ES-Qual (e-SQ) which includes dimensions of efficiency, system availability, fulfillment, and privacy. Rafiq et al. (2012) use the e-SQ model in internet-based retail sales, using only three dimensions, namely efficiency, system availability and sufficiency.

\section{B. Website Quality}

WebQual or Website Quality is a way of measuring the quality of a site based on the perceptions of visitors. WebQual is a Servqual (Service Quality) development that has been widely used to measure the quality of a service. WebQual has a basic measurement function in Quality Function Deployment (QFD) (Fitzgerald \& Bias, 2016; Loiacono et al., 2007).

The latest version of WebQual, WebQual 4.0, examines three main aspects of a site, namely information quality, interaction and usability.

\section{Quality of Mobile Applications (Mobile Apps Quality)}

According to (V. Lee et al., 2004) mobile application is the process of developing applications for electronic devices such as PDAs, corporate digital assistants or mobile phones, these applications are already on the phone during manufacturing, or downloaded by customers from application stores and from distribution. another mobile platform software.

According to (Pressman \& Maxim, 2014) mobile applications are applications that have been specially designed for mobile platforms (iOS, Android, or Windows Mobile). In many cases, mobile applications have user interfaces with unique interaction mechanisms provided by mobile platforms, interoperability with web-based resources that provide access to a wide variety of information relevant to the application, and local processing capabilities for collection, analysis, and formatting of information by means of most suitable for mobile platforms. Additionally the mobile application provides persistent storage capabilities within the platform. 


\section{Customer Satisfaction}

According to Kotler \& Armstrong (2012) defines customer satisfaction as the level of performance that the buyer feels towards the suitability of a product.

Satisfaction is also defined as a customer's assessment of a particular product or service, on whether the product or service can meet their needs and expectations (Zeithaml et al., 2010). (Tjiptono \& Chandra, 2015) defines customer satisfaction as a person's feeling of pleasure or disappointment as a result of comparing the perceived performance of the product and whether it meets its expectations. According to Kotler \& Keller (2016), one of the keys to retaining customers is customer satisfaction. According to (Irawan, 2008) customer satisfaction is a set of consumer perceptions about the performance of a product or service and if the latter meets their expectations. Customers are satisfied when a product or service meets or exceeds their expectations.

\section{E. Framework}

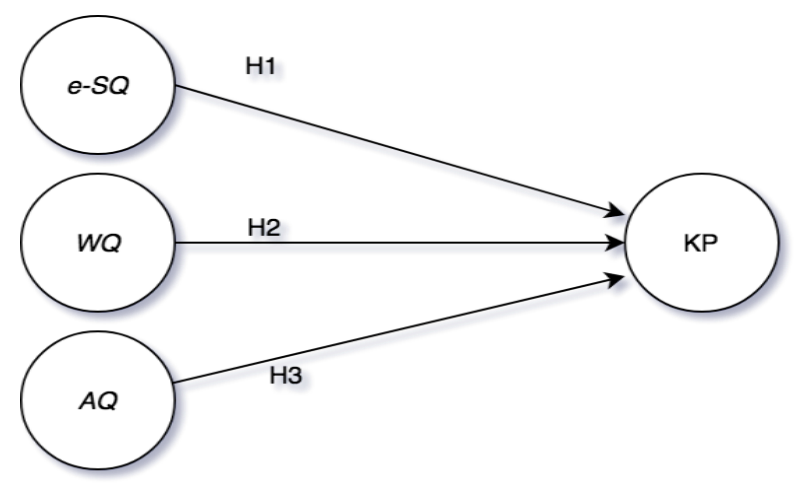

Fig 2:- Conceptual Framework

\section{F. Hypothesis}

The hypothesis is a temporary answer or provisional assumption to the research problem that has been formulated based on the theories used and is related to support the discussion of variables. The hypotheses put forward include:

1) H1: e-Service Quality has a significant positive effect on Customer Satisfaction.

2) H2: Website Quality has a significant positive effect on Customer Satisfaction.

3) H3: Mobile App Quality has a significant positive effect on Customer Satisfaction.

\section{METHODOLOGY}

\section{A. Type of Research}

This research is a quantitative study with a qualitative approach to seeing customer satisfaction. The variables used are variables of the influence of $e$-service quality, website quality, and quality of mobile applications on customer satisfaction variables.

\section{B. Population and Sample}

The population in this study were Shopee or tokopedia users. The data collection technique used in this research is Non Probability Sampling, which is determined that the respondent is a shopee and / or Tokopedia user who is a worker, housewife, entrepreneur, student aged 18-65 years, provided that they have used and transacted on the Shopee website. and / or Tokopedia. The number of samples in this study was taken based on (Ferdinand, 2002; Ketchen, 2013), namely the number of indicators multiplied by 5 to 10. This study used 35 indicators, resulting in a range between 175 to 350 samples of website \& online shopping application users at Shopee. With these considerations, it was finally decided to collect 200 respondents for the Shopee marketplace and 200 respondents for the Tokopedia marketplace.

\section{Data Collection Methods}

Data collection method used in this research is with the data of primary through interviews to the customers who assisted with the questionnaire online. Secondary data obtained from literature studies, journals, and reliable sources. This research was conducted in a desk study with data collection through a questionnaire which was submitted online via mailchimp / surveyymonkey / google docs .

\section{Data analysis method}

The data analysis technique in this study used Structural Equation Modeling-Partial Least Square (SEM-PLS). Ghozali (2014) describes 5 stages of SEM-PLS analysis, namely conceptualizing the model, determining the algorithm of the analysis method, determining the resampling method, drawing path diagrams and evaluating the model.

\section{RESULTS AND DISCUSSION}

\section{A. Characteristics of Respondents \\ $>$ Characteristics of Shopee Respondents}

The total number of respondents who filled this questionnaire online is 200 people, with the percentage of female respondents at $57.5 \%$, higher than the percentage of male respondents $(42.5 \%)$. The age level of respondents was dominated by the age level of 21-30 years as many as 64 people $(32 \%)$, with the lowest percentage of respondents aged 51-60 years (13\%). In the age range of 21-30 years, 33 respondents were women. There were 14 male respondents aged 21-30 years with private occupations and 113 people with the latest education level dominated by diploma / bachelor degree (56.50\%), namely 45 men and 68 women. At the level of occupation, respondents are dominated by respondents who work as private employees as many as 59 people with the largest number of them being male. The respondents who work as students have the lowest percentage of $2.00 \%$. 


\section{- Characteristics of Tokopedia Respondents}

Based on the to tal of 200 respondents who filled out questionnaires Tokopedia, male respondents had a higher percentage value that is equal to $67 \%$ compared to female respondents $(33 \%)$. The majority of respondents were 21 30 years old, namely 71 people $(35.5 \%)$. Respondents aged 51-60 years have the lowest percentage, namely 29 people (14.5\%). Respondents aged 21-30 years were predominantly male, namely 47 people (23.5\%). The education level of the respondents was dominated by diplomas / undergraduate graduates as many as 102 people (51\%) consisting of men (64 people) and women (38 people). Respondents' occupations were dominated by entrepreneurs / professionals as many as 59 people $(29.5 \%)$ with the majority of them being male. The respondents who did not or had not worked had the lowest percentage of $1.50 \%$.

\section{B. Indicator Analysis \\ $>$ Discussion of Shopee Indicators}

The Shopee model consists of 4 latent variables, namely, e-Service Quality (e-SQ), Website Quality (WQ), Mobile Application Quality (AQ), and Customer Satisfaction (CS). The variables e-SQ, WQ, and AQ consist of several dimensions and indicators while the customer satisfaction (KP) variables consist of 12 indicators.

\section{- Indicators on the variable e-Service Quality(e- $S Q)$}

There are 11 dimensions in the e-Service Quality variable. Based on the percentage of respondents 'answers, the majority of respondents' answers varied from neutral to strongly agree on the indicators of the e-service quality variable. This shows a positive response from respondents, indicating that respondents agree that Shopee digital services are reliable and trusted, provide clear information, provide fast and effective responses, are easy and can be accessed at any time, are easy to use, guarantee customer security and privacy, provide many choices (product, price, service), comfortable to use and also has an attractive appearance.

\section{- Indicators on Variable Website Quality (WQ)}

Based on the percentage of respondents' answers, the majority of respondents gave the majority of answer choices Neutral to Strongly Agree on indicators of the 10 dimensions of the Website Quality variable. This shows a positive response from respondents who gave a good assessment that the Shopee website has an adequate and functioning system, is easily accessible to visitors, provides the latest product and service information, is reliable, has accurate, honest, and open information, has featuresfeatures that are complete and easy to understand, and provide reliable information and services.

\section{- Indicators on Mobile Apps Quality Application}

Based on the percentage of respondents' answers, many respondents answered neutral to strongly agree on the indicators of the 11 dimensions that exist in the mobile application quality variable. This shows a positive response from the respondent, which means that the respondent agrees enough to strongly agree that the Shopee mobile application can help customers increase their knowledge about products and get smarter in shopping, services can be adjusted according to preferences, access history, and how to shop for each individual. Shopee mobile has an attractive appearance and is easy to understand, features development continues for the convenience and convenience of customers, has accurate and up-to-date information quality, has interesting content, has various options, and is up to date, provides fast response, provides convenience and variety choices in transactions, provide adequate accommodation, and provide simple, fast, and reliable administrative services.

\section{- Indicators on Shopee \\ Satisfaction Variables}

The overall results of this variable indicate that the most respondents answered agree to strongly agree on all indicators of customer satisfaction variables with an average percentage above $30 \%$. This means that as Shopee customers, respondents are satisfied to the point that they are very satisfied with their experience of visiting and shopping at Shopee. The indicator with the highest percentage of answers is the whole process of using Shopee digital services so that they are willing to go back to purchasing products/services using Shopee digital services (Customersatisfaction 12) as many as $44.5 \%$ of respondents answered strongly agree. This shows that customers are very satisfied with the whole process of using Shopee digital services so they are willing to go back to purchasing products / services using Shopee digital services.

\section{$>$ Discussion on Tokopedia Indicators}

The Tokopedia model consists of 4 latent variables, namely, e-Service Quality (e-SQ), Website Quality (WQ), Mobile Application Quality (AQ), and Customer Satisfaction (KP). The variables e-SQ, WQ, and AQ consist of various dimensions and indicators, while the KP variables only consist of 12 indicators and are dimensions .

\section{- Indicators on the variable e-Service Quality (e-SQ)}

Based on the percentage of respondents' answers, the majority of respondents gave the majority of answer choices Neutral to Strongly Agree on the indicators of the e-Service Quality variable. This shows a positive response from respondents who gave a good assessment that Tokopedia has technical functions that function well on the site and application, and is reliable and trustworthy in terms of service accuracy, accurate product information and payment security. Tokopedia provides effective information to customers and Tokopedia digital services are always ready to respond to customer requests. Tokopedia digital services provide clear information to customers when services can be performed. Respondents considered Tokopedia easy to contact, easy to contact when they needed help. Tokopedia both in terms of product search, means of delivery, by purchase or payment and service digital Tokopedia can be accessed anytime. Tokopedia has intuitive functions so customers can easily and quickly access the features they want. Tokopedia provides a trustworthy image, both from 
the services and products sold as well as a statement that Tokopedia digital service has a good reputation and provides clear and accurate information to its customers. The appearance of the site and application is easy to understand so as to provide comfort and convenience for customers and Tokopedia can adjust to the customer's situation. This shows a positive response from respondents to Tokopedia.

\section{- Indicators on Variable Website Quality (WQ)}

Based on the percentage of respondents' answers, the majority of respondents gave the majority of answer choices Neutral to Strongly Agree on the indicators of the 10 dimensions of the Website Quality variable. This shows a positive response from respondents who gave a good assessment that the Tokopedia website has an adequate and functioning system, is easily accessible to visitors, provides the latest product and service information, is reliable, has accurate, honest, and open information, has featuresfeatures that are complete and easy to understand, and provide reliable information and services.

\section{- Indicators on the Mobile Apps Quality Application}

Based on the percentage of respondents' answers, the majority of respondents gave the majority of answer choices Neutral to Strongly Agree on the indicators of the Mobile Apps Quality variable. It shows the positive response of respondents who give good ratings that Tokopedia increase customer knowledge in online shopping, add customer knowledge in a specific product and usability As well as assisting in the management financial its better.Tokopedia can dikus to misasi suit user preferences, in terms of Tokopedia display that suits your needs and is easy to understand. Tokopedia because it continues to develop / update every feature that makes it easier for customers to shop. Quality information on mobile products apps Tokopedia. Tokopedia provides product delivery speeds that are as promised, Tokopedia service contacts are quick to respond to user complaints or questions. Respondents also rated Tokopedia as easy to use and easy to find the desired product when using the Tokopedia application and respondents rated Tokopedia as easy to make transactions in terms of payment. This shows a positive response from respondents to Tokopedia.

\section{- Indicators on Tokopedia \\ Satisfaction Variables}

Customer

Based on the percentage of respondents' answers the most respondents answered agree to strongly agree on all indicators of customer satisfaction variables with an average percentage above $30 \%$. This means that as Tokopedia customers, respondents are satisfied to the point that they are very satisfied with their experience of visiting and shopping at Tokopedia digital services. This shows that customers are satisfied with the quality of the products they buy through Tokopedia digital services .

\section{Model Analysis \\ $>$ Shopee Model Analysis}

The analytical model used in this study is the application of parceling techniques. The results of data processing using SEM with SmartPLS 3.2 software, consists of 2 parts, namely the outer model and inner model.

\section{- Outer Model}

Figure 3 is the result of processing the initial outer model data. Outer model will produce validity and reliability tests. Based on the results of using SEM-PLS with the validity test in Figure 3, it can be seen that the loading factor value of the manifest variable is more than 0.5 so that all manifest variables in the model are declared valid.

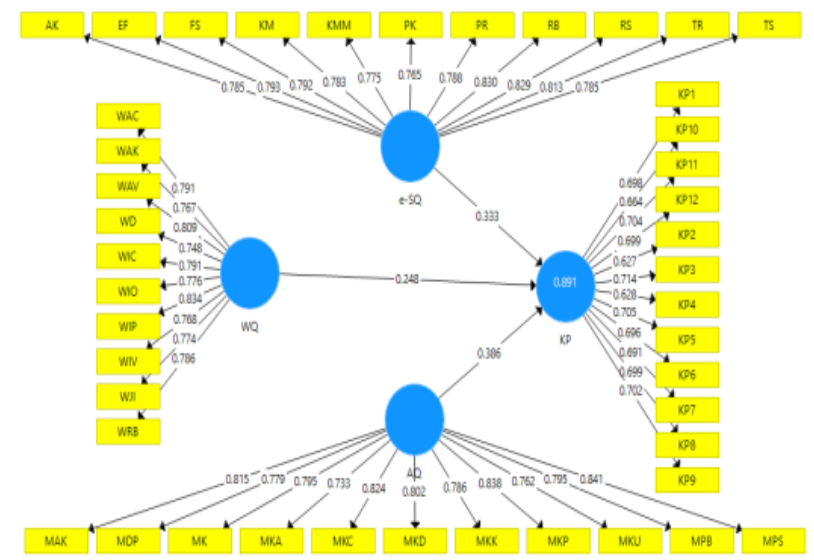

Fig 3: - The Outer Shopee initial model

Based on the results using SEM-PLS, it shows that the variables e-SQ, WQ, and AQ have a Cronbach's Alpha value greater than 0.7 and AVE greater than 0.5 , so that the three variables are declared reliable and pass the reliability test. In contrast to the customer satisfaction (KP) variable, even though it has a Cronbach's Alpha value greater than 0.7 (i.e. 0.897 ), the AVE value is less than 0.5 (i.e. 0.471 ). It is made variable customer satisfaction (KP) is not reliable so do not pass the test of reliability. For this reason, several customer satisfaction (KP) manifest variables will be issued so that the reliability of the customer satisfaction (KP) variable is fulfilled.

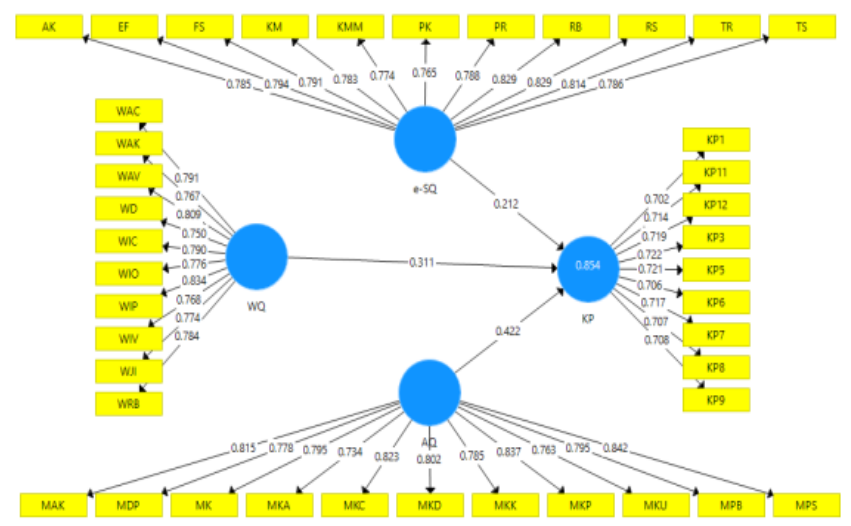

Fig 4: - The outer Shopee final model 
The final outer model can be seen in Figure 4 after several manifest variables of customer satisfaction (KP) variable are excluded. Based on the results using SEMPLS with the validity test showing all manifest variables have a loading factor value of more than 0.5 so that they are declared valid. Then all variables, e-Service Quality (e-SQ), Website Quality (WQ), Mobile Application Quality (AQ), and Customer Satisfaction (KP) have a Cronbach's Alpha value greater than 0.7 and an AVE greater than 0.5 so that these variables are declared reliable . Therefore, the final outer model in this study passed the validity and reliability test. Discriminant analysis used three testing criteria, namely the Fornell-Larcker test, cross-loading test and HTMT test. In the FornellLacker test, it is known that the value of all variables against the indicator has an average value of 0.9 , this value has a value that is greater than the requirement $(>0.7)$. This shows that each variable has a homogeneous relationship, multivariate normal and there is a strong correlation between variables. However, there are four variable values that have a value close to the required value, namely the relationship between the Mobile Application Quality (AQ) variable and the Mobile Application Quality (AQ) variable, the Customer Satisfaction (KP) variable against the Customer Satisfaction (KP) variable, the website quality (WQ) variable for the WQ variable and the e-Service Quality (e-SQ) variable for the e-service quality (SQ) variable, each of which has a value of $0.798 ; 0.713 ; 0.785$ and 0.795 . This is due to the lack of a homogeneous relationship and shows symptoms of multicollinearity even though it has a small possibility. The cross-loading test is used to determine whether the variables have a significant correlation with each other. In the results using SEM-PLS, it is known that the cross-loading values for each variable are roughly $0.6,0.7$ and 0.8 . The results obtained have a value that exceeds the requirements $(>0.5)$ and has a value that is greater than the other indicators, thus indicating that each tested variable has a high level of significance and fulfills the value in the discriminant validity test requirements. HTMT test is used to determine the level of specificity and sensitivity of a factor. Values obtained pa da test is above 0.9 that had qualified (> 0.9). This shows that each indicator has a specific level and is sensitive to good indicators so that it meets the requirements for use in discriminant validity. The three criteria tested in discriminant validity have met the requirements, so that each indicator has a homogeneous, multicollinearity, and significant relationship. Therefore, each indicator can be said to meet the standard requirements.

\section{- Inner Model (Hypothesis Test)}

The $R$-square value generated from this research model amounted to 0.854 or $85.4 \%$. This shows that the variables e-Service Quality (e-SQ), Website Quality (WQ), Mobile Application Quality (AQ) together are able to explain the Customer Satisfaction (KP) variable by $85.4 \%$ and the remaining $14.6 \%$ is explained by other variables outside of this research model. The F-Square value shows that the F-Square values on the A e-Service Quality (e-SQ), Website Quality (WQ), Mobile Application
Quality (AQ) indicators are $0.11,0.075$ and 0.029, respectively. The three indicators are categorized as indicators that have a weak or small influence in the structural order because they have a value of $<0.20$. Therefore, the model under study belongs to the weak model category.The Q-Square test is used to test how well the observation value generated by the model and its parameters. The results of data testing for the Q-Square Test using SEM-PLS show that the Shopee Q-Square value has a value of 0.428 . This value is a value above 0 and close to 1 , so it can be said that the model tested is a model that is fit with the data so that it can be said that each indicator and variable can be said to be valid and reliable.

\begin{tabular}{|c|c|c|c|}
\hline Criteria & $\begin{array}{c}\text { Estimated } \\
\text { Model }\end{array}$ & $\begin{array}{c}\text { Critical } \\
\text { Points }\end{array}$ & Information \\
\hline SRMR & 0.038 & $<0.08$ & Fit Model \\
\hline NFI & 0850 & $>0.9$ & $\begin{array}{c}\text { Model Not } \\
\text { Fit }\end{array}$ \\
\hline $\begin{array}{c}\text { Theta } \\
\text { rms }\end{array}$ & 0.091 & $<0.12$ & Model Fit \\
\hline \multicolumn{2}{|r}{}
\end{tabular}

Table 1: - Shopee Model Fit Measurement

Source: primary data processed (2019)

The model fit test in this study uses the fit model (goodness of fit) which can be seen from the SRMR, NFI, and Theta rms values.

Based on Table 1, the NFI criteria are categorized as not fit because they have an estimated model value that is smaller than 0.9, while the SRMR and Theta rms criteria are said to be fit because they meet the critical point requirements. Based on this, more than $50 \%$ of the existing goodness of fit criteria have been met, so the model that has been built in this study is declared good / fit.

Inner model describes the relationship and influence between latent variables that are built. This model consists of 4 latent variables, namely e-Service Quality (e-SQ), Website Quality (WQ), Mobile Application Quality (AQ), and Customer Satisfaction (KP). The four variables consist of 3 independent variables e-Service Quality (e-SQ), Website Quality (WQ), Mobile Application Quality (AQ) and 1 dependent variable Customer Satisfaction (KP). The results of the inner model can be seen in Figure 5.

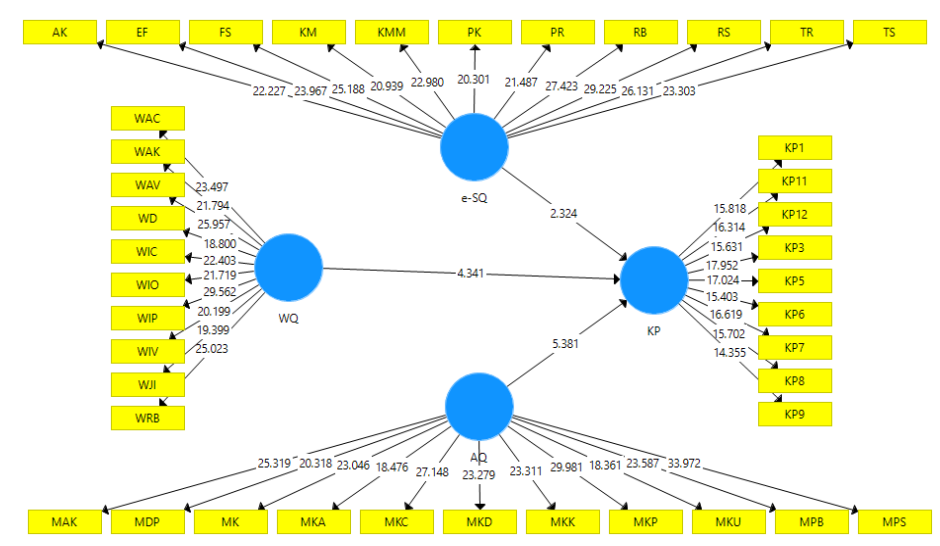

Fig 5:- Inner model Shopee 
Inner model is used to analyze the hypothesis that is built. The hypothesis is accepted if the T statistical value is greater than 1.96 (with a confidence interval of $95 \%$, error 5\%) and the $P$ value is less than 0.05 . In addition, to see that the independent variable has a positive or negative effect on the dependent variable, it can be seen from the original sample value. A positive original sample value indicates that the influence between latent variables is also positive and vice versa.

\begin{tabular}{|c|c|c|c|c|}
\hline & $\begin{array}{c}\text { Original sample } \\
(\mathbf{O})\end{array}$ & $\begin{array}{c}\text { T statistics }(\mid \mathbf{O} / \\
\text { STDEV })\end{array}$ & P values & Information \\
\hline $\begin{array}{c}\text { e-Service Quality -> } \\
\text { Customer Satisfaction }\end{array}$ & 0.212 & 2,324 & 0.021 & Positive Significance \\
\hline $\begin{array}{c}\text { Website Quality -> Customer } \\
\text { Satisfaction }\end{array}$ & 0.311 & 4,341 & 0.000 & Positive Significance \\
\hline $\begin{array}{c}\text { Mobile Apps Quality -> } \\
\text { Customer Satisfaction }\end{array}$ & 0.422 & 5,381 & 0.000 & Positive Significance \\
\hline
\end{tabular}

Table 2: - Original Sample, T Statistics, P Value from Inner Model Shopee

Source: primary data processed (2019)

\section{$\checkmark$ H1: The e-Service Quality variable has a positive and significant effect on Shopee Customer Satisfaction}

Table 2 shows that the $e$-Service Quality variable has a positive relationship with Customer Satisfaction which can be seen from the original sample value, which is 0.212 . This value indicates that an increase in the $e$ Service Quality variable by $100 \%$ will increase the Customer Satisfaction by $21.2 \%$. The e-Service Quality $t$ statistics is greater than 1.96, which is 2.323 and the $p$ value is less than 0.05 , which is 0.021 . For this reason, $e$ Service Quality has a significant positive effect on Customer Satisfaction so that the hypothesis (H1) is accepted .

\section{$\checkmark$ H2: Website Quality variable has a positive and significant effect on Shopee Customer Satisfaction}

The positive relationship between Website Quality and customer satisfaction can be seen from the original sample value of 0.311 in table 4.72 . This value also indicates that an increase in the Website Quality variable by $100 \%$ will increase the customer satisfaction by $31.1 \%$. Website Quality also has a significant effect on Customer Satisfaction as described by $t$ statistics which is more than 1.96, which is 4.341 and a $p$ value that is less than 0.05 , which is equal to 0.000 . for that Website Quality has a significant positive effect on Customer Satisfaction so that the hypothesis (H2) is accepted. This means that increasing website quality will increase customer satisfaction with Shopee website services.

\section{$\checkmark$ H3: The Mobile Apps Quality variable has a positive and significant effect on Shopee Customer Satisfaction}

Mobile Apps Quality has a positive effect on Customer Satisfaction. It can be in view of the value original sample of 0.422 . This value also showed that the increase in variable Mobile Apps Quality of $100 \%$ will increase by $42.2 \%$ Customer Satisfaction . The significant effect of the Mobile Apps Quality variable on Customer Satisfaction is known from $t$ statistics of 5,381 which is greater than 1.96 and a $\mathrm{p}$ value of less than 0.05 , which is equal to 0.000. for that Mobile Apps Quality has a significant positive effect on Customer Satisfaction so that the hypothesis (H3) is accepted. This means that the increasing quality of mobile applications will increase customer satisfaction with Shopee mobile application services

\section{> Analysis of the Tokopedia Model \\ - Outer Model}

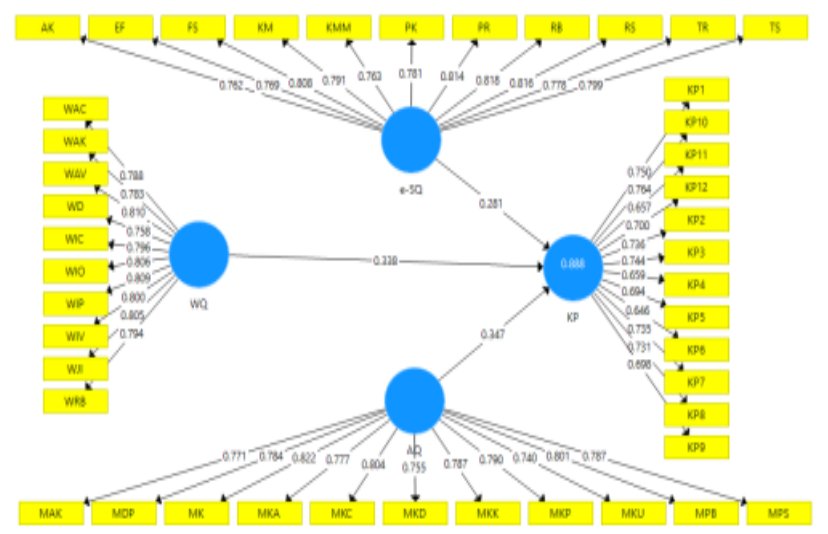

Fig 6: - Tokopedia outer model

The results of Tokoped's outer model can be seen in Figure 6. Based on Figure 6, using SEM-PLS for the validity test, it is known that the loading factor of the manifest variable is greater than 0.5 . These results make all manifest variables of the model meet the validity test so that all manifest variables of the e-Service Quality (e-SQ), Website Quality (WQ), Mobile Application Quality (AQ), and Customer Satisfaction (KP) variables are declared valid. After testing the validity, reliability testing continued with e-Service Quality (e-SQ)latent variables, Website Quality (WQ), Mobile Application Quality (AQ), and Customer Satisfaction (KP) otherwise reliable as seen from the value of Cronbach's Alpha and AVE. The four latent variables have a Cronbach's Alpha value greater than 0.7 and an AVE value greater than 0.5 so that they pass the reliability test. 
Fornell-Lacker test with SEM-PLS has a result the average value of 0.9 , indicating that each variable has a homogeneous relationship, multivariate and have a strong correlation. However, the value of the Mobile Application Quality (AQ)variable for the Mobile Application Quality (AQ) variable, the Customer satisfaction (KP) variable for the KP variable, the Website quality (WQ) variable for the website quality variable and the e-service quality variable for the e-service quality variable have values of 0.784 , $0.711,0.795$, and 0.791 respectively, this happens because of the lack of a homogeneous relationship.

The cross-loading test using SEM-PLS shows that the cross-loading values for each variable are roughly 0.6 , 0.7 and 0.8 , but have more values on an average of 0.7 and 0.8 , so they have a good value because exceeds the requirements and has a value that is greater than the other indicators. Therefore, each tested variable shows a high level of significance.

The HTMT test with SEM-PLS shows the value above 0.9 , so it can be said to have met the requirements (> 0.9). This shows that each indicator has a specific level and is sensitive to good indicators so that it meets the requirements for use in discriminant validity. The three criteria tested in discriminant validity have met the requirements, so that each indicator has a homogeneous, multicollinearity, and significant relationship. Therefore, each indicator can be said to meet the standard requirements and deserves to be tested for discriminant validity.

\section{- Inner Model (Hypothesis Test)}

The R-squared of the Tokopedia model is 0.888 . This means that the three independent variables (e-SQ, WQ, and AQ) together are able to explain the dependent variable customer satisfaction ( KP) by $88.8 \%$ and the remaining $11.2 \%$ is explained by other variables outside of this research model . The greater the Rsquared means that the independent variable is better able to explain the dependent variable.
F-Square Test that the F-Square on indicators $e$ Service Quality (e-SQ), Website Quality (WQ), Mobile Application Quality (AQ) each are $0.122,0.114$ and 0.068 . The e-Service Quality (eSQ), Website Quality (WQ), Mobile Application Quality (AQ) indicators are categorized as indicators that have a weak and small effect $(<0.20)$ on the structural order. So it can be concluded that the model under study is a simple model that helps researchers in making research easier. The results of the Tokopedia Q-Square test have a value of 0.441 . This value is a value above 0 and close to 1 , so it can be said that the model tested is a model that is fit with the data so that it can be said that every indicator and variable can be said to be valid and reliable.

\begin{tabular}{|c|c|c|c|}
\hline Criteria & $\begin{array}{c}\text { Estimated } \\
\text { Model }\end{array}$ & $\begin{array}{c}\text { Critical } \\
\text { Points }\end{array}$ & Information \\
\hline SRMR & 0.038 & $<0.08$ & Fit Model \\
\hline NFI & 0849 & $>0.9$ & $\begin{array}{c}\text { Model Not } \\
\text { Fit }\end{array}$ \\
\hline $\begin{array}{c}\text { Theta } \\
\text { rms }\end{array}$ & 0.085 & $<0.12$ & Fit Model \\
\hline
\end{tabular}

Table 3:- Tokopedia Model Fit Measurement Source: primary data processed (2019)

Based on Table 3, the Tokopedia model has also met the model fit. This can be seen from the value of the estimated model for the SRMR and Theta rms criteria which have met the critical point requirements. Although the NFI criteria do not meet the goodness of fit requirements, the other 2 criteria have met, so that more than $50 \%$ of the existing goodness of fit criteria have been met. Thus the model that has been built in this study (in the Tokopedia model) is declared good / fit.

The relationship between Tokopedia latent variables can be seen from the inner model results. In addition, the results of the inner model will explain the results of testing the hypotheses that are built. The result of the Tokope inner model can be seen in Figure 7 and Table 4 .

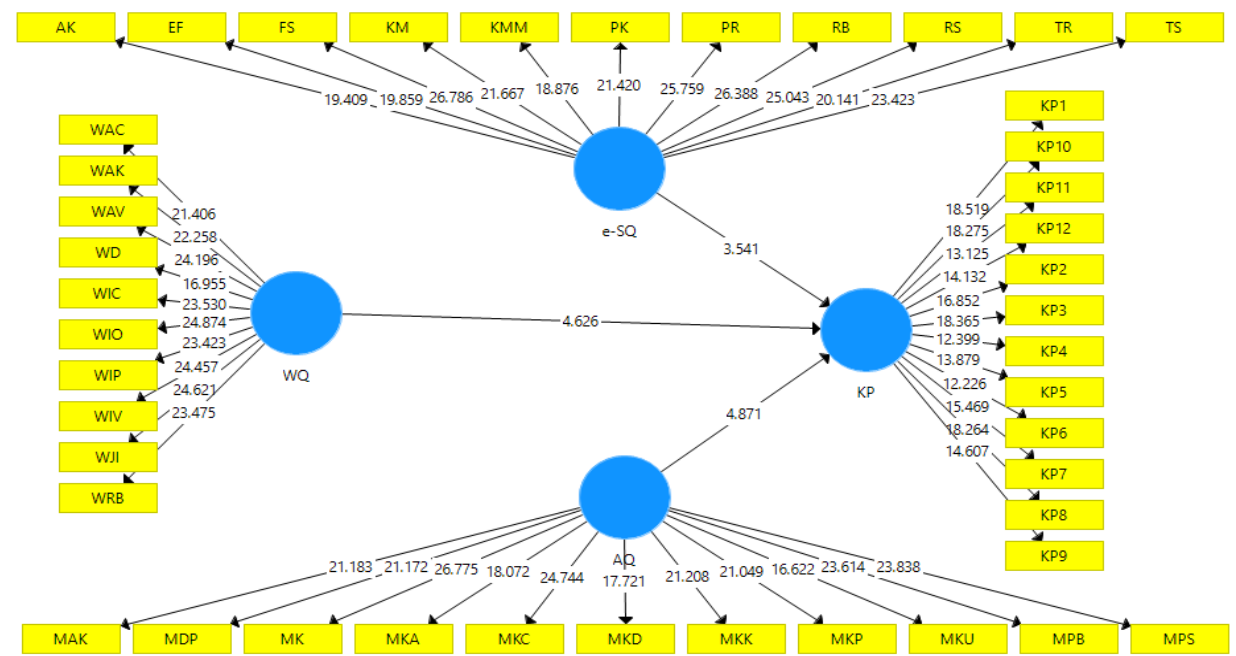

Fig 7: - Inner model of Tokopedia 
ISSN No:-2456-2165

\begin{tabular}{|c|c|c|c|c|}
\hline & $\begin{array}{c}\text { Original sample } \\
(\mathbf{O})\end{array}$ & T statistics $(|\mathbf{O} / \mathbf{S T D E V}|)$ & $\boldsymbol{P}$ value & Information \\
\hline $\begin{array}{c}\text { e-Service Quality -> } \\
\text { Customer Satisfaction }\end{array}$ & 0.347 & 4,871 & 0.000 & Positive Significance \\
\hline $\begin{array}{c}\text { Website Quality -> } \\
\text { Customer Satisfaction }\end{array}$ & 0.338 & 4,626 & 0.000 & Positive Significance \\
\hline $\begin{array}{c}\text { Mobile Apps Quality -> } \\
\text { Customer Satisfaction }\end{array}$ & 0.281 & 3,541 & 0.000 & Positive Significance \\
\hline
\end{tabular}

Table 4: - Original Sample, T Statistics, P Value from Tokopedia Inner Model

Source: Primary data processing (2019)

\begin{abstract}
$\checkmark$ H1: The e-Service Quality variable has a positive and significant effect on Tokopedia Customer Satisfaction

Based on Table 4, the variable e-Service Quality significantly influence the customer satisfaction can be seen from the $t$ statistics greater than 1.96 are at 4,871 and $p$ value less than 0.05 ( ie for 0000 ). E-service quality is also positively related, which is known from the original sample value, which is 0.347 . This value also indicates that if e-service quality increases $100 \%$ it will increase customer satisfaction by $34.7 \%$. E-service quality has a significant positive effect on customer satisfaction so that the hypothesis is accepted.
\end{abstract}

\section{$\checkmark$ H2: Website Quality variable has a positive and significant effect on Tokopedia Customer Satisfaction}

Based on Table 4 , it can be seen that the Website quality variable is positively related to customer satisfaction which can be seen from the original sample of 0.388 . This also means that when Website quality can be increased by $100 \%$, customer satisfaction will increase by $38.8 \%$. The $T$ statistics of Website quality is 4,626 which is greater than 1.96 and the $p$ value of 0.000 (less than 0.05 ) makes Website quality have a significant effect on customer satisfaction. Therefore, it can be said that Website Quality has a significant positive effect on customer satisfaction so that the hypothesis is accepted.

\section{$\checkmark$ H3: The Apps Quality variable has a positive and significant effect on Tokopedia Customer Satisfaction}

Table 4 shows that the variable Mobile apps quality significant effect on the variable customer satisfaction views of $t$ statistics greater than 1.96 are at 3,541 and $p$ value less than 0.05 is equal to 0.000 . The original sample Mobile apps quality value of 0.281 indicates a positive relationship between Mobile apps quality and customer satisfaction. This means that the Mobile apps quality variable has a significant positive effect on the customer satisfaction variable so that the hypothesis is accepted (reject $\left.\mathrm{H} 3_{0}\right)$.

\section{Managerial Implications}

The company is expected to improve E-service Quality because increasing it will have an impact on customer satisfaction for Shopee digital services. If it is related to the number of respondents' answers in the e-service quality questionnaire, there are still many respondents who answer neutral, which can be used as a reference to see what services need to be improved from $e$-service quality to increase customer satisfaction. With increased customer satisfaction, customers' willingness to recommend to other relations / people and also willing to re-purchase products/services using Shopee digital services will be greater.

- Website quality has a significant positive effect on customer satisfaction. This means that increasing website quality will increase customer satisfaction with Shopee website services.

$>$ Factors such as availability, accessibility, durability, duration of information, reliability, accuracy, completeness, objectivity, ease of understanding, and validity of the information used as dimensions in this study can be used as a reference to further improve the quality of Shopee website services to increase customer satisfaction.

Mobile applications have a significant positive effect on customer satisfaction, meaning that the increasing quality of mobile applications will increase customer satisfaction

with Shopee mobile application services. Factors such as intelligence, customization, appearance, development, data quality, content quality, speed, personalization, ease of use, accommodation needs, and administrative quality which are the dimensions in this study are important factors that can be used as references in improving service quality. Shopee mobile application to increase customer satisfaction.

E-service quality has a significant positive effect on customer satisfaction, increasing e-service quality will increase customer satisfaction with Tokopedia digital services. The dimensions in this research variable are important factors for increasing Tokopedia customer satisfaction.

> Increasing website quality will also increase customer satisfaction

with the Tokopedia website services. Therefore, the dimensions that are in the latent variable of website quality are important factors that need to be considered to increase Tokopedia customer satisfaction.

The dimensions that represent the variable quality of mobile applications are important factors in increasing customer satisfaction, factors such as intelligence, customization, appearance, development, data quality, content quality, speed, personalization, ease of use, accommodation needs, and quality. administrative 
dimensions in this study are important factors that can be used as references in improving the quality of Tokopedia mobile application services.

\section{CONCLUSIONS AND RECOMMENDATIONS}

\section{A. Conclusion}

- e-Service Quality has a positive and significant impact on customer satisfaction in the Shopee marketplace

$>$ Website Quality has a positive and significant influence on customer satisfaction in the Shopee marketplace

$>$ Mobile apps quality has a positive and significant impact on customer satisfaction in the Shopee marketplace

$>e$-Service Quality has a positive and significant impact on customer satisfaction on the Tokopedia marketplace

- Website Quality has a positive and significant impact on customer satisfaction on the Tokopedia marketplace

$>$ Mobile Apps Quality has a positive and significant impact on customer satisfaction on the Tokopedia marketplace

$>$ Based on the results of hypothesis testing in this study, the three independent variables, namely e-Service quality, Website quality, and Apps quality proved to have a significant positive effect on the dependent variable customer satisfaction on Shopee and Tokopedia digital services. However, the three independent variables have different influences on the Shopee and Tokopedia marketplaces .

$>$ At Shopee, apps quality is the variable with the largest original sample value, indicating consumers assess Strongly Agree that the Shopee application can give a personal impression and make respondents feel bound by the application (MPS1). Meanwhile, in Tokopedia, AQ is the variable with the smallest original sample value of 0.281 . This indicates that Tokopedia customer satisfaction from the Application Quality Variable is not as high as consumers who use Shopee. Tokopedia users assess the Tokopedia Mobile Application as having the least effect in determining their satisfaction compared to other variables.

$>$ At Shopee, e-service quality is the variable with the smallest influence on Customer Satisfaction while in Tokopedia, the e-service quality variable has the largest positive and significant effect. These results indicate that Shopee users assess service quality at Shopee as still having a significantly lower impact and its effect than the effect of mobile applications and websites in terms of customer satisfaction. On the other hand, Tokopedia customers assess the quality of online services (e-Service Quality) provided by Tokopedia as a whole as more important and have a significant effect than mobile applications or websites. In other words, the Tokopedia brand is considered by its users to consistently have higher quality services, regardless of which media the customer uses, both from the website and from the application.

$>$ Both Shopee and Tokopedia users assess website quality as a variable that has a significant influence. On Shopee and Tokopedia, website quality is in the second position in terms of its influence. This shows that both Shopee and Tokopedia have designed their websites in a quality manner to meet consumer needs well.

\section{B. Suggestion}

Suggestions for Marketplace

After conducting the analysis results, some suggestions that can be considered for the Shopee and Tokopedia marketplaces are:

\section{- Suggestion for Shopee Marketplace}

$\checkmark$ Communicating the strength of Shopee services in terms of reliability (functioning properly, reliable, accurate product information, as a solution to problems faced by customers. Safe and reliable payment transaction processing) and Responsiveness (speed of seller response, speed of payment, on time delivery.

$\checkmark$ In general, the image of the Shopee Website as a marketplace that has reliable, easy to use and understand quality information can be a concern of Shopee management if it wants to strengthen and increase the segment of users who want to access services through the website and increase.

$\checkmark$ The Shopee Mobile application is the biggest access point for users to use the Shopee marketplace . Aspects personalization become the strongest point of a pplication mobile Shopee, where applications considered capable of providing personal impression for customers and committed to Shopee as a shopping platform of online options

$\checkmark$ By communicating strength (strength) in the Website and Shopee Application and fixing the things that customers think are not good, Shopee can get better customer satisfaction and can increase better customer loyalty. When customer loyalty is good, the high costs for promotion can be reduced and reduce the burden on the company.

\section{- Suggestion for Tokopedia Marketplace}

$\checkmark$ Tokopedia is advised to communicate the strength of Tokopedia services in terms of reliability because the reliability dimension is the highest dimension in explaining Tokopedia Service Quality ( $e-S Q$ ), as well as improving customer perceptions about customer accessibility (Access) because it has the lowest value in terms of Tokopedia service quality.

$\checkmark$ Tokopedia can encourage sellers to respond more quickly to potential buyer questions and pay more attention to customer service in responding to customer complaints or questions so that they are served faster. With a focus on improving service quality (eSQ), it will encourage higher customer satisfaction compared to improving the quality of mobile applications and websites (based on the OR value).

$\checkmark$ Customer access through the Tokopedia Website in this study covers $20 \%$ of the respondents, this shows that the Website has a less dominant role for users in accessing Tokopedia. However, the OR value indicates that an increase in Website Quality has the second highest increase in providing better customer satisfaction. It is recommended for Tokopedia to maintain 
the availability aspect, both in terms of service (information on product availability and quality, communication with sellers and information on the purchase process and product delivery to customers) and improve aspects of Website Durability (disturbances / errors on the website and loading speed of website features ) which still gets a low response from customers.

\section{Suggestions for Further Research}

Suggestions for further research to consider and enrich variables, dimensions, other indicators related to customer satisfaction in the digital era, and increase the number of respondents.

\section{REFERENCES}

[1]. Adellia, N., \& Prasetio, A. (2016). Customer Perception Mapping Analysis of Indonesian Ecommerce Marketplace Sites based on Attributes Usability, Site Design, Information Quality, Trust, and Empathy ( Case Study of Tokopedia , Bukalapak, Elevenia ,. 4th International Conference on Cyber and IT Service Management. https://ieeexplore.ieee.org/document/7577580

[2]. Ferdinand, A. (2002). Structural Equation Modeling dalam Penelitian Manajemen (1st ed.). Badan Penerbit Universitas Diponegoro.

[3]. Fitzgerald, M. P., \& Bias, T. K. (2016). Satisfaction and Repurchase Intentions for Health Insurance Marketplaces: Evidence from a Partnership State. Journal of Consumer Affairs, 50(3), 638-651. https://doi.org/10.1111/joca.12088

[4]. Ghozali, I. (2014). Partial Least Squares: Konsep Metode dan Aplikasi Menggunakan Program WarpPLS 4.0. Semarang: Penerbit Universitas Diponegoro

[5]. IPrice. (2019a). Peta E-Commerce Indonesia. IPrice. https://iprice.co.id/insights/mapofecommerce/

[6]. IPrice. (2019b). Peta E-Commerce Indonesia. IPrice.

[7]. Irawan, H. (2008). Indonesian customer satisfaction: membedah strategi kepuasan pelanggan merek pemenang ICSA (2nd ed.). Elex Media Komputindo. https://books.google.co.id/books?id=5DpVlT_ypBkC

[8]. Ketchen, D. J. (2013). A Primer on Partial Least Squares Structural Equation Modeling. In Long Range Planning (Vol. 46, Issues 1-2). https://doi.org/10.1016/j.lrp.2013.01.002

[9]. Kotler, Philip, \& Keller, K. L. (2016). Marketing Management, 15th Edition (15th ed.). Pearson Education. https://www.pearson.com/us/highereducation/product/Kotler-Marketing-Management15th-Edition/9780133856460.html

[10]. Kotler, Phillip, \& Amstrong, G. (2012). PrinsipPrinsip Manajemen (Edisi 14). Airlangga.

[11]. Lee, V., Schneider, H., \& Schell, R. (2004). Mobile Applications: Architecture, Design, and Development. Pearson Education. https://books.google.co.id/books?id=XA1TAAAAMA AJ
[12]. Parasuraman, A., Zeithaml, V. A., \& Malhotra, A. (2005). E-S-QUAL a multiple-item scale for assessing electronic service quality. Journal of Service Research, 7(3), 213-233. https://doi.org/10.1177/1094670504271156

[13]. Pressman, R. S., \& Maxim, B. R. (2014). Software engineering: A practitioner's approach (8th ed.). McGraw-Hill https://www.amazon.com/Software-EngineeringPractitioners-Roger-Pressman/dp/0078022126

[14]. Putri, R. O., Wibawa, B. M., \& Laksamana, T. (2017). Identifikasi Permasalahan Komplain pada ECommerce Menggunakan Metode Fishbone. Jurnal Sains Dan Seni ITS, 6(1). https://doi.org/10.12962/j23373520.v6i1.21485

[15]. Rafiq, M., Lu, X., \& Fulford, H. (2012). Measuring Internet retail service quality using E-S-QUAL. Journal of Marketing Management, 28(9-10), 11591173. https://doi.org/10.1080/0267257X.2011.621441

[16]. Tjiptono, F., \& Chandra, G. (2015). Pemasaran Strategik (1st ed.). Penerbit Andi.

[17]. Wolfinbarger, M., \& Gilly, M. C. (2003). eTailQ: Dimensionalizing, measuring and predicting etail quality. Journal of Retailing, 79(3), 183-198. https://doi.org/10.1016/S0022-4359(03)00034-4

[18]. Zeithaml, V. A., Parasuraman, A., \& Malhotra, A. (2002). Service quality delivery through web sites: A critical review of extant knowledge. Journal of the Academy of Marketing Science, 30(4), 362-375. https://doi.org/10.1177/009207002236911

[19]. Zeithaml, V., Bitner, M., \& Gremler, D. (2010). Services Marketing Strategy. https://doi.org/10.1002/9781444316568.wiem01055 